\title{
The Impact Of Using Computer Software On Vocabulary Learning Of Iranian EFL University Students
}

\author{
Samira Pahlavanpoorfard \\ Department of Language and Literature, Islamic Azad University, Larestan Branch, Iran \\ E-mail: samira_pahlavanpoorfard@yahoo.com \\ Afshin Soori \\ Department of Language and Literature, Islamic Azad University, Larestan Branch, Iran \\ E-mail: afshin_soori@yahoo.com
}

Received: 11-01-2014

doi:10.7575/aiac.ijalel.v.3n.4p.23
Accepted: 25-02-2014

Published: 01-07-2014

\begin{abstract}
Today, using computer is common in all fields. Education is not an exception. In fact, this approach of technology has been using increasingly in language classrooms. We have witnessed there are more and more language teachers are using computers in their classrooms. This research study investigates the impact of using computer on vocabulary learning of Iranian EFL university students. To this end, a sample of 40 university students in Islamic Azad University, Larestan branch were randomly assigned into the experimental and control groups. Prior the treatment and to catch the initial deferences between the participants, all the students sat for a pre-test that was an Oxford Placement Test. Then the students were received the treatment for 10 weeks. The students in the experimental group were taught by computer software for vocabulary learning while the students in the control group were taught through traditional method for vocabulary learning. After the treatment, all the students sat for a post-test. The statistical analysis through running Independent-Sample T-tests revealed thatthe students in the experimental group who used the computer software for vocabulary learning performed better than the students in the control group were taught through traditional method for vocabulary learning.
\end{abstract}

Keywords: Technology, Computer, Vocabulary learning, EFL students

\section{Introduction}

Today all aspects of human lives have been affected by the era of information technology and technology plays an important role in developing the human society. The world of education is a massive area that is under the influence of technology. Needless to say, applying technology to learning and teaching a second or foreign language is an important educational issue. Although using technologies have become so widespread in education and their uses have dramatically expanded, the application of technology in language classrooms is a challenging area for teachers and researchers who like to utilize this new approach in education. Technology can cause some changes in teaching of foreign language. Among different technologies, computer "forces pedagogy to think in new ways to exploit the computers benefits and work around its limitations" (Barani 2012, p. 532).

Warschauer (1998)points out the increasing use of computer in educational settings. To Hewer (2007) the application of Computer Assisted Language Learning (CALL) in the area of modern language teaching and learning has got a high growth of popularity. Using technology can range from software to the internet. CALL is defined as "learners learning language in any context with, through, and around computer technologies" (as cited in Naraghizadeh and Barimani, 2013 , p. 2). Beatty (2003) refers to the connection between CALL and other areas of study like autonomy in language learning and teaching language skills. Hewer (2007) refers to two types of technologies in CALL instruction as software and Internet-based activities.

In order to promote the development of all language skills, CALL can be integrated into the curricula, and making use of multimedia is one form of this integration. Multimedia technologies benefit from texts, pictures, graphics, animations and sounds (Hewer 2007 as cited in Naraghizadeh and Barimani, 2013). Multimedia is an important issue that has been investigated in numerous studies. The findings of different studies (e.g. Al-Seghayer, 2001; Jones \& Plass, 2002; Moreno \& Valdez, 2005; Nikolova, 2002; Tsou, Wang, \& Li, 2002)revealed that multimedia has a positive impact on the learning of languages

CALL is an issue that acts like a bridge between linguists, and computer scientists and as Kenning, and Kenning 1990 , as cited in Naraghizadeh and Barimani, 2013) suggest With the growing sense of unity between them, "some of the mysteries of language acquisition will be unraveled, which can furnish the new locus to language more effective and principled language teaching" (p. 2). Computers can be applied in educational contexts like language testing, language research, and school management.

Vocabulary can be considered as a component which plays a vital role in language learning. According to Kitajima 
(2001) words label objects, actions, and concepts, and without knowing words speakers are not able to express their intended meanings.

In fact, words are the building blocks of language and the lack of them may cause obstacles for learners in learning other aspects of a language. Therefore, a main concern among the language teachers, researchers and practitioners is expanding vocabulary (LIU Jing-hua, 2009). In many cases, as the students were not taught by effective techniques, they tended to forget the meaning of the words. Words are the units of meaning and sentences, paragraphs, and whole texts are making from words.Teaching or learning vocabulary can be considered as a critical area that needs some special attentions.

In recent years, computer technology has accelerated and facilitated vocabulary learning. To a large number of researchers (e.g. Baker and Wilson, 1995; Lam \& Pennington, 1995; McEnery, Warden, 1995; Neu and Scarcella, 1991)educational software can contribute learning languages. During the past few decades the number of teachers using computers in the language classrooms has been dramatically increased. In fact, the appearance of CALL provided a new outlook for vocabulary learning (Tabar \& Khodareza, 2012).Computer assisted vocabulary learningis considered as one of the most application of CALL. This can be considered as a new tool for vocabulary instruction. Therefore it has drawn the attention of teachers and researchers. As a result, many empirical studies have tried to apply computer assisted vocabulary learning effectiveness on vocabulary achievement.

Baumann \& Kameenui, (1991) refer to argument over the strategy of teaching vocabulary as the "fertility versus futility debate". By referring to some empirical studies, advocates of vocabulary instruction suggest a higher efficacy for the direct instruction of vocabulary. On the opposite side, some researchers do not believe in the futile side of the debate and argue "in favor of vocabulary development within a broader educational framework that provides opportunities for students to map word meanings onto existing schemas" (Nagy, \& Hermann, 1987 as cited in Naraghizadeh and Barimani, 2013, p.3).

Among numerous researchers, Wood (2001) is one who advocates "teaching practices that combine both direct instruction of unknown words and incidental learning of vocabulary in natural contexts" (p.3). According to Wood, neither explicit instruction of word meaning nor incidental learning of vocabulary can be a appropriate strategy for the learning of the vocabulary when used exclusively. Instead, rich learning of vocabulary will happen as a result of applying both approaches correctly (Wood, 2001). To this end, CALL can make use of these two approaches by combine them together. However, making use of this technology depends on the learners to be able to play with new items, assimilate them, and make use of them on their own. As Jones and Fortescue (1987) state that some students prefer to take word games and some other students make a list of vocabulary and then memorize them.

The findings of the research on computer-assisted vocabulary learning have significant impacts on software designs used for CALL (Naraghizadeh and Barimani, 2013). "By surveying vocabulary acquisition theories, guiding principles for the design of CALL programs for vocabulary have been suggested or the researchers have described programs they developed for vocabulary teaching" (Son, 2001).These studies point to how software can be developed or used in CALL environments and how the students learn how to use CALL for learning vocabulary.

For an ongoing experimental project, Horst, Cobb, and Nicolae (2005) created a set of on-line tools for vocabulary learning. The tools they had designed included some resources like concordance, dictionary, hypertext, and a database with interactive self-quizzing features. These tools were supposed to facilitate learners' deep processing. The students should insert vocabulary information (e.g. example sentences, parts of speech, and definitions) on a collaborative online word bank by themselves. A post-test was examined to find the gain of their vocabulary knowledge. The findings of their study revealed that the words were entered in the word bank were learned more than the words were not entered. Regarding the result of many different studies indicated that on-line vocabulary learning lead to more input. The findings of another study by Jones (1999) showed the positive reactions toward application of computer programs for learning vocabulary and possibility of computer use for vocabulary learning.

Regarding vocabulary development, it seems that CALL has great advantages over the previous technologies like cassette recorder. Jones and Fortescue (1987 as cited in Naraghizadeh and Barimani, 2013) believe that "Since, its clarity and attractiveness of presentation, its games-manager role, its availability at all hours and its flexibility in supplying for the preferences of different users, are motivating force to enhance vocabulary acquisition" (p.24).

\section{Statement of the Problem}

According to McCarthy (1988), the major part of the meaning of any language in learning a second language is the amount of vocabulary one possesses.To many researchers (Coady and Huckin, 1997; Harley, 1996; Nation, 2001) an essential component of second and foreign language proficiency is vocabulary learning. The meaning is conveyed by words and a major obstacle in using second language effectively is lack of vocabulary (Krashen 1989). Regarding this issue, vocabulary learning has attracted the attentions in second language learning. It seems that the finding of the previous studies on vocabulary learning is not conclusive and it is a controversial issue for the researchers on how the learners can learn vocabulary effectively and efficiently. For many years the traditional method that includes a memorization of a long list of words and explicitly providing the students with paired translation equivalents has been using in language classrooms in Iran. The problem is that traditional method lacks any theoretical support and the vocabulary learning is more than memorization of long list of wordsin the target language. To Nation (1990) understanding a word means understanding its spelling, pronunciation, and appropriateness. To this end, the memorization of the target words with their equivalents cannot be an effective method for learning vocabulary. This 
traditional method seems an ineffective method for learning vocabulary that has been used for many decades. In this case, it is time to turn to a new approach or method that is using technology such as computer for learning vocabulary for Iranian EFL university students.

\section{Objective of the Study}

The current study is supposed to provide a new outlook toward using technology for learning vocabulary instead of applying traditional method in language classrooms. In other words, this study likes to investigate the effectiveness of using computer for vocabulary learning among Iranian EFL students in Larestan Islamic Azad University. Regarding this issue, the research question will be as follows:

1. Is computer software effective in learning vocabulary among Iranian EFL university students in comparison with traditional method of vocabulary learning?

\section{Participants}

The participants of the current study were a sample 40 male and female intermediate university students at Larestan Islamic Azad University. They were all English major students. To be sure of homogeneity among the participants of the study In order to validate the language proficiency of the students and make up a homogeneous group, students were given the Oxford Placement Test (OPT). In this case, it can be said that there exists equivalence between the experimental groups and the control groups since all groups sat for a placement test. Regarding the results of the OPT, 20 students were randomly assigned into the experimental and 20 students were randomly assigned into control group.Gender was not considered as a variable to be controlled in this study.

\section{Instruments}

Different types of instruments were used in this study like Oxford Placement Test, the word lists, the vocabulary tests, and a computer software .

\section{Procedure for the experimental group}

To catch the initial difference between the groups a pre-test was fulfilled during the first session of the experiment. In the first session the students received a brief explanation about the purpose of the study by the researcher. Then, the students installed the software on their laptops that had been told to bring to the class. The students were allowed to ask their questions about the software. Then, they practiced the software in order to know how to work with it. The students were asked to take part in class twice a week on different days for the ten weeks. In the second session, the researcher brought the words' source file in to the classroom. These words' source files are provided to the students at the beginning of every session. The students clicked the main window, and then main lists were appeared that included ten words. Each word contained meaning, difficulty level, and phonetic symbol. The students were able to hear the pronunciation of the words. In the second part, the words could be displayed and pronounced automatically. In the third part, the students could practice the spelling of the words. The definitions of the words were also appeared automatically. The students could also write the spelling of the words. If the students wrote the spelling wrongly, the software alarmed that meant the spelling of the words were incorrect. After that, the correct spelling and the student's spelling were appeared. In the fourth part, the students were given a multiple-choice vocabulary test. The items of the tests were taken from the vocabulary had been worked on during the sessions. By the test, the students were able to choose meaning by word or choose word by meaning. Based on the students' selection, the students could choose the correct definition or word. The last two parts were games. In the memory part, there were some cards that should be matched with each other. On one card it was written the word and on the other it was written the meaning. If the student clicked one card, the card would display the content what it holds. When another card was clicked by the student, if they were matched, they would disappear, otherwise, the first one hide the content. When all cards were disappeared, the student was the winner in the game. This procedure was repeated in all sessions. After the students received the treatment, they received a post-test to evaluate the effects of the treatment.

\section{Procedure for the control group}

In each session, the students in control group received usual classroom instruction. Like the students in experimental group, the students in control group received a pre-test to catch the initial differences between groups. The students were asked to follow the steps in order to teach the new words.

At first, the students were allowed to read each word twice or three times with a short pause. The students were able to check the pronunciation, and identify the syllable which received the primary stress.

In the second step, the students are allowed to read each word two or three times again and they repeat the words. This was done in chorus with individual spot checks. Then, the researcher asked all the students to repeat the word once more again.

In the third step, the students opened their books and listened to the words for two or three times.

In the last step, the students reviewed the list of vocabulary and tried to explain each word by giving examples or they wrote synonyms or antonyms for the words. After the treatment, the students received a post-test to check the effect of instruction.

\section{Data Analysis}

As the aim of this study was to compare using computer for vocabulary learning with traditional method of vocabulary learning, vocabulary tests were used for data collection. 
These two methods of vocabulary learning were compared based on the students' vocabulary achievement. Thus, the independent variable was two methods of vocabulary instruction. The dependent variable was vocabulary test scores. The Statistical Package for Social Sciences' software program (SPSS 20.0) was used to analyze the data. To do the statistical analysis and to compare these two methods, an Independent-Sample T-Test was run because both experimental and control groups were independent from each other. After the treatment, both groups were given a posttest. The same statistical procedure was run here as well. An Independent-Sample T-Test was runto compare the means between both experimental and control groups.

\section{Results and discussion}

1. Research Question:Is computer software effective in learning vocabulary among Iranian EFL university students in comparison with traditional method of vocabulary learning?

To know which one is more effective vocabulary learning achievement computer software or traditional method,both experimental and control groups were compared according to their results in pre and post-test scores separately. To this end, first the results of students' scores in pre-test were analyzed to be sure whether the students in both groups were homogeneous based on their vocabulary knowledge.Then, their scores on post-test were analyzed to check the effect of treatment. The results of two Independent-Sample T-Testone before the treatment and one after the treatment. Table 1indicates the descriptive statistics of the pre-test before the administration of the treatment given to students, and Table 2 displays the results of running an Independent-Sample T-test before the administration of the treatment.

Table 1. Descriptive statistics of the pre-test given to students

\begin{tabular}{clllll}
\hline & Groups & $\mathrm{N}$ & Mean & $\begin{array}{l}\text { Std. } \\
\text { Deviation }\end{array}$ & $\begin{array}{l}\text { Std. Error } \\
\text { Mean }\end{array}$ \\
\hline \multirow{2}{*}{ Data } & $\begin{array}{l}\text { Computer Software } \\
\text { Group }\end{array}$ & 20 & 3.2795 & 1.7865 & .5386 \\
& & & & .5765 \\
& $\begin{array}{l}\text { Traditional Method } \\
\text { Group }\end{array}$ & 20 & 3.4896 & 1.9467 & \\
\hline
\end{tabular}

Table 1 describes the statistics of the pre-test given to students before the treatment. The results show that there is no significant difference between these two groups before treatment.

Table 2. Independent-Sample T-Test comparing Computer Software Group and Traditional Method Group

\begin{tabular}{clllllll}
\hline & \multicolumn{7}{c}{ t-test for Equality of Means } \\
\cline { 2 - 7 } & $\mathrm{F}$ & $\mathrm{Si}$ & $\mathrm{t}$ & $\mathrm{df}$ & $\begin{array}{l}\text { Sig. (2- } \\
\text { tailed) }\end{array}$ & $\begin{array}{l}\text { Mean } \\
\text { Difference }\end{array}$ & $\begin{array}{l}\text { Std. } \\
\text { Difference }\end{array}$ \\
\hline Data & .003 & .849 & - & 38 & .674 & -.28563 & .59643 \\
\end{tabular}

As shown in Table 2, the mean score of the Computer Software Group $(\mathrm{M}=3.2795)$ is almost the same as Traditional Method Group $(\mathrm{M}=3.4896)$. Then a t-test was run to see whether or not the difference was significant. As indicated in Table 2, the Independent-Sample T-test result (.674) represents that there is no meaningful distinction between the means of the two groups before the treatment. Thus, it can be said that the vocabulary knowledge of the two groups was almost the same before the treatment.

To examine the effect of the treatment, the participants' scores in post-test were analyzed. An Independent-Sample ttest was run to compare the means of both groups after treatment. Table 3 shows the descriptive statistics of the posttest after the treatment given to students. Table 4 indicates the results of Independent-Sample T-test after the treatment.

Table 3. Descriptive statistics of the post-test given to students

\begin{tabular}{lllllc}
\hline & Groups & $\mathrm{N}$ & Mean & $\begin{array}{l}\text { Std. } \\
\text { Deviation }\end{array}$ & $\begin{array}{l}\text { Std. Error } \\
\text { Mean }\end{array}$ \\
\hline \multirow{2}{*}{ Data } & Computer Software & 20 & 30.4596 & 4.2587 & .83935 \\
& \begin{tabular}{l} 
Group \\
\cline { 2 - 5 }
\end{tabular} & 20 & 21.3693 & 4.7932 & .97456 \\
& $\begin{array}{l}\text { Traditional Method } \\
\text { Group }\end{array}$ & & & \\
\hline
\end{tabular}


Table 3 indicates descriptive statistics of the post-test given to students after the treatment.

Table 4. Independent-Sample T-Test comparing Computer Software Group and Traditional Method Group

\begin{tabular}{cccccccc}
\hline & \multicolumn{7}{c}{ t-test for Equality of Means } \\
\cline { 2 - 8 } & F & Sig. & t & df & $\begin{array}{l}\text { Sig. (2- } \\
\text { tailed) }\end{array}$ & $\begin{array}{l}\text { Mean } \\
\text { Difference }\end{array}$ & $\begin{array}{l}\text { Std. } \\
\text { Difference }\end{array}$ \\
\hline Data & 1.009 & .369 & 4.579 & 38 & .000 & 5.85000 & 1.4379 \\
\hline
\end{tabular}

As indicated in Table 4 the mean score of the computer software group $(\mathrm{M}=30.4596)$ is considerably higher than the mean scores of the traditional method group $(\mathrm{M}=21.3693)$.

Then a T-test was run to see whether or not the difference was significant. As shown in Table 4, T-test result (.000) revealed that there is a meaningful distinction between the means of the two groups in the post-test after the treatment. The results of T-test showed that the performance of computer software group was higher than the performance of the traditional method group. Therefore, using computer for vocabulary learning is more effective than traditional method.

\section{Discussion \& Conclusion}

The current study attempted to compare the effect of using computer in learning vocabulary with the traditional method in learning vocabulary on Iranian EFL university students' vocabulary knowledge. The findings of the study indicated that computer group had a better performance than that of the traditional group, and the students in computer group learned more vocabulary than the students in traditional method group. The better performance of the using computer group was in terms of vocabulary achievement that can be described because of the following factors. The students could control their learning during the implementations. According to Lee, (2000) and McGreal (1988) this can be an individualized learning that has promoted the motivation among the students. Therefore, this motivation has facilitated learning vocabulary. Another issue is related to the one to one interaction between the students and the computers which can make the vocabulary learning easier. Another reason refers to immediate feedback from the computer when it corrects the mistakes committed by the students. Students were only people who could see the answers. Therefore, students did not have any fear for making mistakes. This situation causes low affective-filter environment. Therefore, it facilitates languagelearning (Krashen, 1982). The result of this study was in line with the findings of previous studies (Fu, 2002; Levine, Frenz and Reves, 2000) that expressed that computer can facilitate vocabulary learning.

\section{References}

Al-Seghayer, K. (2001). The effect of multimedia annotation modes on L2 vocabulary acquisition: A comparativestudy. Language Learning \& Technology, 5 (1), 202-232.

Barani, G. (2012). The impact of computer assisted language learning (CALL) on vocabulary achievement of Iranian university students EFL learners, International Journal of Basic Sciences \& Applied Research. 2 (5), pp. 531-537.

Beatty, K. (2003). Teaching and researching computer-assisted language learning. London:Pearson Education.

Coady, J. \& Huckin, T. (1997). Second language vocabulary acquisition. London: Cambridge University Press.

Fu, Y. H. (2002). The effect of computer-assisted language learning (CALL) on fifthgrade Taiwanese students'English vocabulary learning through reading. Unpublished Doctoral Dissertation. The University ofMississippi.

Harley, B. (1996). Introduction: Vocabulary learning and teaching in a second language. The Canadian ModernLanguage Review, 53 (1), 3-11.

Hewer, S. (2007). CALL methodology: integrating CALL into study programs. Module 2.1. In Davies G. (Ed.), Information and communications technology for language teachers (ICT4LT). Slough, Thames Vally University. Retrieved from the World Wide Web: http://www.ict4lt.org/en/en-mod2-1.htm.

Horst, M., Cobb, T., \& Meara, P. (1998). Beyond A Clockwork Orange: Acquiring second language vocabulary through reading [Electronic version]. Reading in a Foreign Language, 11(2), 207-223.

Jones, C. (1999). Contextualize and personalize: Key strategies for vocabulary acquisition [Electronic version]. RECALL, 11(3), 34-40.

Jones, Ch., \& Fortescue, S. (1987). Using computers in the language classroom. London: Longman Group UK Limited.

Jones, L. C., \& Plass, J. L. (2002). Supporting listening comprehension and vocabulary acquisition in French with multimedia annotation [Electronic version]. The Modern Language Journal, 86, 546-561.

Kenning, M. J., \& Kenning, M. M. (1990). Computer and language learning: Current theory and practice. New York: Ellis Horwood Limited.

Krashen, S. (1989). We acquire vocabulary and spelling by reading: Additional evidence for the input hypothesis.The Modern Language Journal, 73, 440-464. 
Lam, F. S., \& Pennington, M. C. (1995). The computer vs. the pen: A comparative study of word processing in aHong Kong secondary classroom. Computer Assisted Language Learning (CALL): An International Journal,8(1), 75 - 92.

Lee, K. (2000). English teachers' barriers to the use of computer assisted language Learning. The Internet TESLJournal, $6(12)$.

Levine, A., Ferenz, O., \& Reves, T. (2000). EFL academic reading and modern technology: How can we turn ourstudents into independent critical readers? TESL- EJ, 4 (4).

LIU, J.-h. (2009). The integration of CALL to vocabulary teaching and learning. US-China Foreign Language, ISSN1539-8080, USA.

McCarthy (1988). Vocabulary and language teaching. New York: Longman.

McEnery, T., Baker, J. P., \& Wilson, A. (1995). A statistical analysis of corpus based computer vs. traditional human teaching methods of part of speech analysis. Computer Assisted Language Learning (CALL): An InternationalJournal, $8(2), 259-274$.

Moreno, R. \& Valdez, A. (2005). Cognitive load and learning effects of having students organize pictures and words in multimedia environments: the role of student interactivity and feedback [Electronic version]. ETR \& D, 53(3), 35-45.

Nagy, W. E., \& Herman, P. A. (1987). Breadth and depth of vocabulary knowledge: Implications for acquisition and instruction. In M. G. McKeown \& M. Curtis (Eds.). The nature of vocabulary acquisition (pp. 19-35). Hillsdale, NJ: Erlbaum.

Naraghizadeh, M. and, Barimani, S. (2013). The effect of CALL on the vocabulary learning of Iranian EFL learners, Journal of Academic and Applied Studies, 3( 8), pp. 1-12.

Nation, I. S. P. (1990). Teaching and learning vocabulary. New York: Newbury House Publishers.

Neu, J. and Scarcella, R. (1991). Word processing in the EFL writing classroom. In: P. Dunkel (Ed.), ComputerassistedLanguage Learning and Testing: Research Issues and Practices. New York: Newbury House.

Nikolova, O. R. (2002). Effects of students' participation in authoring of multimedia materials on student acquisition of vocabulary [Electronic version]. Language Learning \& Technology, 6(1), 100-122.

Son, J. B. (2001). CALL and vocabulary learning: A review [Electronic version]. English Linguistic Science, 7, 27-35.

Tabar1, H. and Khodareza, M. (2012). The effect of using multimedia on vocabulary learning of pre-intermediate and intermediate Iranian EFL learners, Journal of Basic and AppliedResearch,2, 12, pp. 12879-12891

Tsou, W., Wang, W., \& Li, H.-Y. (2002). How computers facilitate English foreign language learners acquire English abstract words [Electronic version]. Computers \& Education, 39, 415-428.

Warschauer M, Healey D, 1998. Computers and language learning: an overview. Language Teaching. 31: 57-71.

Wood, J. (2001). Can software support children's vocabulary development? LLT journal. 5(1), 166-201 URL:http://11t.msu.edu. 